\title{
COMPARATIVE ANALYSIS OF CERVICAL SAGITTAL BALANCE WITH RADIOGRAPHS IN DIFFERENT POSTURES
}

\author{
ANÁLISE COMPARATIVA DO EQUILÍBRIO SAGITAL CERVICAL COM RADIOGRAFIAS \\ EM DIFERENTES POSTURAS
}

\section{ANÁLISIS COMPARATIVO DEL EQUILIBRIO SAGITAL CERVICAL CON RADIOGRAFÍAS EN DIFERENTES POSTURAS}

\author{
Vania Maria Lima, ${ }^{1}$ Guilherme Reiff Toller, ${ }^{1}$ Nilson Mozas Olivares ${ }^{2}$ \\ 1. Centro Universitário Padre Albino - UNIFIPA, Department of Orthopedics and Traumatology, Catanduva, SP, Brazil. \\ 2. Centro Universitário Padre Albino - UNIFIPA, Department of Statistics, Course in Medicine, Catanduva, SP, Brazil.
}

\begin{abstract}
Objective: To compare the cervical sagittal balance in groups of patients submitted to lateral radiographs of the cervical segment, with the upper limbs in two different positions. Methods: This is a cross-sectional, quantitative, prospective, descriptive study using radiographic analysis of 100 adult individuals, aged between 20 and 70 years. Two lateral radiographs were taken of each patient, one image with the upper limbs crossed over the trunk (flexed elbows) and the other with the upper limbs elevated in front (extended elbows). All patients answered a questionnaire about age, sex, presence of pain in the cervical spine, as well as degree of pain based on the Likert scale. The radiographic parameters evaluated were the COBB angle (Cobb), thoracic inlet angle (TIA), T1 slope, neck tilt and distance from the center of gravity (COG) of the skull to C7 (COG-C7) with the elbows in extension (Ext) and flexion (Flex). A p-value of less than 0.05 was considered a statistically significant difference. Results: Sixty patients were female (60\%) and forty were male (40\%). The data analysis obtained showed statistical significance in Cobb Flex vs. Cobb Ext $(p=0.000)$, TIA Flex vs. TIA Ext $(p=0.000)$, T1 Flex vs. T1 Ext ( $p=0.000)$, Neck tilt Flex vs. Neck tilt Ext $(p=0.000)$, and COG-C7 Flex vs. COG-C7 Ext $(p=0.000)$. Conclusion: There was statistical significance in relation to the positioning of the upper limbs in the lateral radiographs, yielding higher values in the angulations with the limbs raised towards the front (extended elbows). Level of evidence II; Prospective Comparative Study.
\end{abstract}

Keywords: Spine; Postural Balance; Radiography.

\section{RESUMO}

Objetivo: Comparar o equilíbrio sagital cervical em grupos de pacientes submetidos a radiografias laterais do segmento cervical, com os membros superiores em duas posições distintas. Métodos: Trata-se de um estudo transversal, quantitativo, descritivo prospectivo por meio de análise radiográfica de 100 indivíduos adultos com idade entre 20 e 70 anos. Duas radiografias na incidência lateral foram obtidas de cada paciente, sendo uma imagem com os membros superiores cruzados sobre o tronco (cotovelos fletidos) e outra com os membros superiores elevados à frente (cotovelos estendidos). Todos os pacientes responderam a um questionário sobre idade, sexo, presença de dor na coluna cervical, assim como grau de dor baseada na escala de Likert. Os parâmetros radiográficos avaliados foram: ângulo de Cobb (Cobb), ângulo de entrada torácica (TIA), Inclinação de T1, Inclinação do pescoço (Necktilt) e distância do centro de gravidade (COG) do crânio até C7 (COG-C7) com cotovelos em flexão (Flet) e extensão (Est). Considerou-se o valor do p menor que 0,05 para a diferença estatisticamente significante. Resultados: Sessenta pacientes eram do sexo feminino (60\%) e quarenta do sexo masculino (40\%). A análise dos dados obtidos demonstrou significância estatística em Cobb Flet vs. Cobb Est $(p=0,000)$, TIA Flet vs. TIA Est ( $p=0,000)$, T1 Flet vs. T1 Est $(p=0,000)$, Necktilt Flet vs. Necktilt Est $(p=0,000)$, COG-C7 Flet vs. COG-C7 Est $(p=0,000)$. Conclusão: Houve significância estatística com relação ao posicionamento dos membros superiores nas radiografias de perfil, evidenciando valores maiores nas angulações com os membros elevados para frente (cotovelos estendidos). Nível de evidência II; Estudo Prospectivo Comparativo.

Descritores: Coluna Vertebral; Equilíbrio Postural; Radiografia.

\section{RESUMEN}

Objetivo: Comparar el equilibrio sagital cervical en grupos de pacientes sometidos a radiografías laterales del segmento cervical, con los miembros superiores en dos posiciones distintas. Métodos: Se trata de un estudio transversal, cuantitativo, descriptivo, prospectivo por medio de análisis radiográfico de 100 individuos adultos con edad de entre 20 y 70 años. Fueron obtenidas dos radiografías en la incidencia lateral de cada paciente, siendo una imagen con los miembros superiores cruzados sobre el tronco (codos flexionados) y otra con los miembros superiores elevados al frente (codos extendidos). Todos los pacientes respondieron a un cuestionario sobre edad, sexo y presencia de dolor en la columna cervical, así como el grado de dolor basado en la escala de Likert. Los parámetros radiográficos evaluados fueron: ángulo de COBB (Cobb), ángulo de entrada torácica (TIA), Inclinación de T1, Inclinación del cuello (Necktilt) y distancia del centro de gravedad (COG) del cráneo hasta C7 (COG-C7) con codos en flexión (Flet) y extensión (Est). Se consideró el valor del p menor que 0,05 para la diferencia estadísticamente 
significativa. Resultados: Sesenta pacientes eran del sexo femenino (60\%) y cuarenta del sexo masculino (40\%). El análisis de los datos obtenidos demostró significancia estadística en Cobb Flet vs Cobb Est $(p=0,000)$, TIA Flet vs TIA Est $(p=0,000)$, T1 Flet vs T1 Est ( $p=0,000)$, Necktilt Flet vs Necktilt Est ( $p=0,000)$, COG-C7 Flet vs COG-C7 Est $(p=0,000)$. Conclusión: Hubo significancia estadística con relación al posicionamiento de los miembros superiores en las radiografías de perfil, evidenciando valores mayores en las angulaciones con los miembros elevados al frente (codos extendidos). Nivel de evidencia II; Estudio Prospectivo Comparativo.

Descriptores: Columna Vertebral; Balance Postural; Radiografía.

\section{INTRODUCTION}

Human postures have been described by anatomists, such as Staffels, Delmas, and Bonne. However, these were morphological descriptions. In studies of spinal deformity or the presence of pain, its three-dimensional components, such as the center of the head and neck mass, the vertical component of muscular strength, and weight, must be taken into account. ${ }^{1}$ Different deformities can affect the axial, coronal, and sagittal planes, and may involve a combination of abnormalities in multiple planes, compromising sagittal balance. ${ }^{2}$

Sagittal balance is based on the alignment between the vertebral segments. ${ }^{2-4}$ It is a parameter evaluated by means of physical and radiographic examinations, being important in the study of spinal diseases, especially in the planning and indication of surgical treatment. The importance of the sagittal balance of the cervical segment and the fact that its deformity is associated with pain, functional disability, and even with the severity of cervical myelopathy have been demonstrated. ${ }^{4}$

Sagittal balance was measured by Hardacker et al. ${ }^{5}$ using the $\mathrm{CO}$ $\mathrm{C} 1, \mathrm{C} 1-\mathrm{C} 2, \mathrm{C} 2-\mathrm{C} 3, \mathrm{C} 3-\mathrm{C} 4, \mathrm{C} 4-\mathrm{C} 5, \mathrm{C} 5-\mathrm{C} 6, \mathrm{C} 6-\mathrm{C} 7 \mathrm{Cobb}$ method in a sample of asymptomatic patients without complaints of cervical spine or arm pain. The participants were also grouped by the presence or absence of low back pain during the radiographic examination. ${ }^{5}$ However, no mention was made of the positioning of the upper limbs during a lateral radiograph of the cervical spine and the resulting effects that it could have on sagittal alignment and balance. ${ }^{6}$

In more recent studies, measurements of cervical sagittal balance included several radiographic parameters, among them T1 slope or T1 inclination, C1-C2 lordosis, C2-C7 lordosis, sagittal vertical axis (SVA), and C7 and T11 slope., $4,7,8$

T1 slope is correlated with the overall sagittal balance of the spine, including the equilibrium of the cervical spine. ${ }^{4}$ Lee et al.${ }^{9}$ showed that $\mathrm{T} 1$ slope was a determining factor in the sagittal balance of the cervical spine. This can be affected as a result of surgical treatments such as arthrodesis or by deformity from cervical spine diseases. ${ }^{9}$

Despite their importance in relation to cervical spine mobility, there are no publications that define the reference values for the balance of this vertebral segment. ${ }^{9}$ Studies of spinopelvic normality parameters were conducted in a Brazilian population sample, but to date there is no information about normal sagittal balance values for radiographic parameters for the cervical spine. ${ }^{10,11}$

Lee et al. ${ }^{4}$ performed lateral radiographs of the cervical spine in 77 asymptomatic patients between 21 and 50 years of age and evaluated the following parameters: (1) thoracic inlet parameters: thoracic inlet angle (TIA), T1 slope, and neck tilt (NT); (2) cervical spine parameters: C2-7, C0-7 angle.

In the study by Wang et al. ${ }^{3}$ findings indicated that the TIA, the T1 slope, and the neck tilt can be used as indices for evaluating cervical sagittal balance and that the TIA could be used as a reference for assessing cervical compensation. These angles should be considered as an objective of surgical treatment for degenerative disc diseases during preoperative planning.

Despite numerous works comparing the kinematics of cervical flexion and extension during the lateral cervical spine radiographic examination, ${ }^{12-15}$ there is only one study by Vedantam et al. ${ }^{15}$ that relates it to the positioning of the upper limbs at the time of the radiographic examination.

The objective of this study is to determine whether the positioning of the arms in radiographic incidences can alter the evaluation of cervical sagittal balance. This study is relevant due to the scarcity of these analyses in the literature.

\section{METHODS}

This is a cross-sectional, quantitative, descriptive, prospective study of radiographic analyses of the cervical spine relative to two different postures of the patient's arms during the examination. The individuals that participated in the study were volunteers between 20 and 70 years of age who were attended at the multi-specialty outpatient clinic of the HEEC (Hospital Escola Emilio Carlos) Orthopedics and Traumatology Department in Catanduva, SP, during the period from November 2017 to April 2018. One hundred and fifty patients were interviewed. Of these, 13 decided not to participate at the beginning of the study. The group remained with 137 patients (51 men and 86 women) who filled out the Informed Consent Form and answered the questionnaire to obtain age, sex, weight, height, and to evaluate the degree of cervical spine pain. Excluded from the study were one woman who had undergone previous spine surgery, 16 patients for not having radiographs taken, 15 patients with technically inadequate radiographs, and 5 patients with comorbidities in the shoulders that could alter the analysis of the parameters. The final sample consisted of 100 patients, $60 \%$ of them female and $40 \%$ male.

The study was approved by the IRB (Institutional Review Board of the Faculdades Integradas Padre Albino) and the approval opinion was registered as number: 73095817.9.0000.5430 approved on September 14, 2017.

Pain intensity was analyzed by means of a Likert scale based on the Visual Analog and Face Scales. ${ }^{11,16}$ In our study we stratified the pain as zero (no pain), 1 to 4 (mild pain), 5 to 9 (moderate pain) and 10 (the worst pain).

In this study, we standardized two lateral cervical spine radiographs, one with the upper limbs crossed over the trunk and the elbows flexed and the second with the arms raised in $90^{\circ}$ flexion with the elbows extended, both in the orthostatic position and looking straight ahead. The patients were positioned one and a half meters from the collimator, close to the chassis. (Figures 1 and 2) All the images were taken by a single radiology technician. The patients were divided into inclusion and exclusion criteria groups for the study (Figure 3).

The Vestatech Hecra D-0005 -Toshiba device was used for this study.

The angles were measured with a goniometer (Figures 4 and 5) and evaluated by the authors. The radiographic parameters considered were:

1. Cervical lordosis $(\mathrm{CL})$ using the Cobb method, based on the lines parallel to the inferior terminal plates of $\mathrm{C} 2$ and $\mathrm{C} 7$, measured in degrees. ${ }^{6,17-19}$

2. The angle of T1 slope: the angle between a line tangent to the superior terminal plate of $\mathrm{T} 1$ and the horizontal plane, measured in degrees. $6,18,19$

3. Thoracic inlet angle (TIA): delimited by the body of the first thoracic vertebra in the direction of the manubrium and a straight line perpendicular to the upper limit of the jugular notch of the sternum and by the first ribs and the upper edge of the first thoracic vertebra. ${ }^{6,17,18}$ 4. The neck tilt angle is defined as the angle between two lines originating in the upper region of the sternum, one being vertical and the other connecting the sternum to the center of the terminal plate of $\mathrm{T} 1.6,18,19$

5. COG is measured using a line perpendicular to the ground and the center of gravity of the head. In lateral radiographs the COG can be measured using the anterior portion of the external auditory pavilion as the starting point up to the posterior superior aspect of the vertebral body of C7 measured in millimeters. ${ }^{6,18,19}$ 


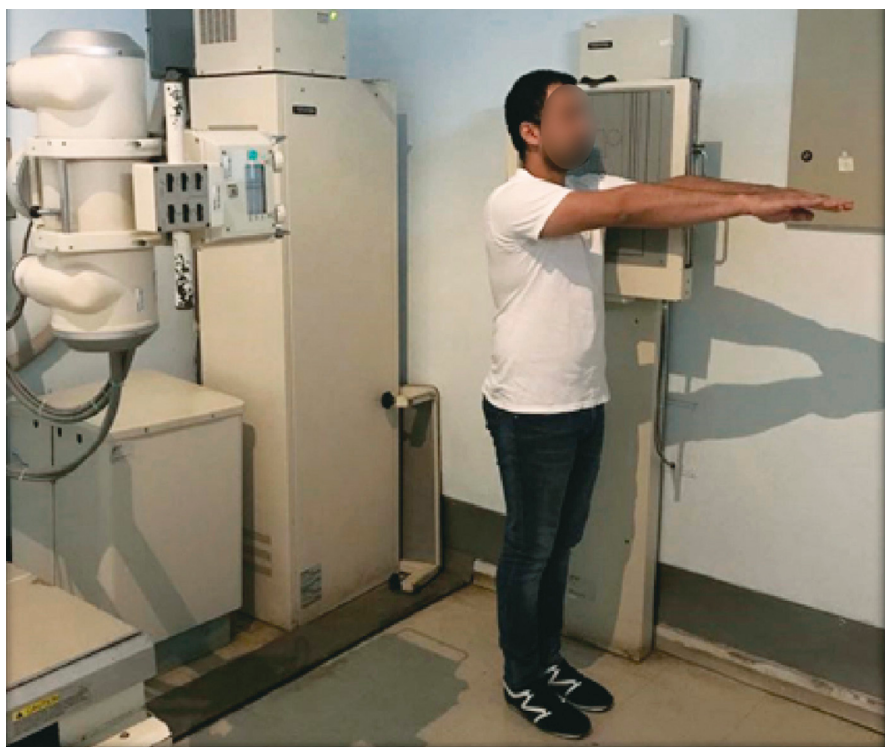

Figure 1. Lateral radiography of the cervical spine with the arms raised horizontally in $90^{\circ}$ flexion in the orthostatic position.

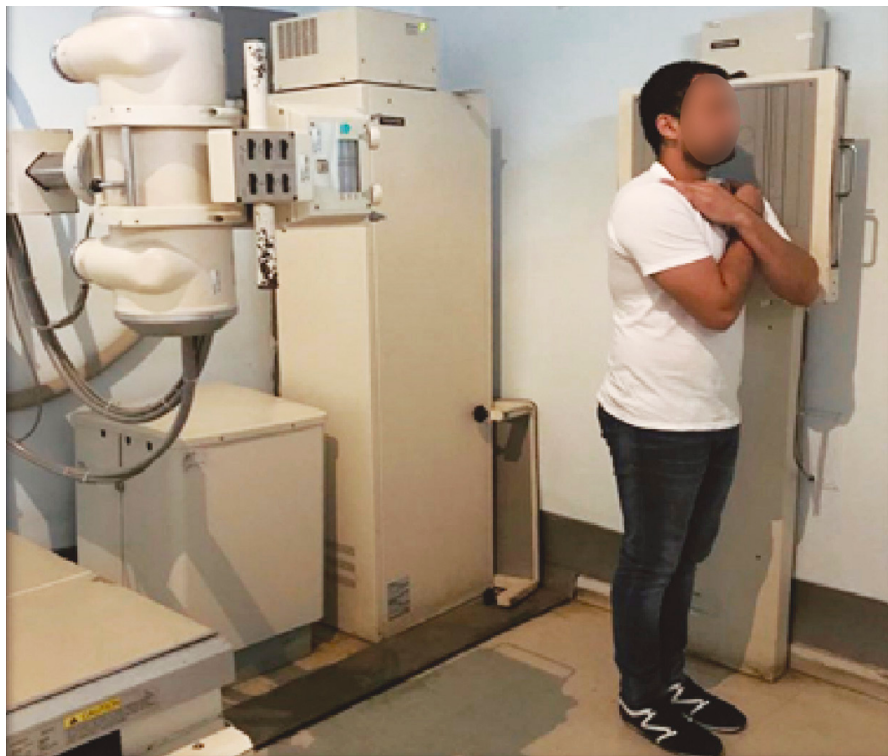

Figure 2. Lateral radiography of the cervical spine with the upper limbs crossed over the trunk in the orthostatic position

\begin{tabular}{|c|c|}
\hline Inclusion & Exclusion \\
\hline Age range 20 to 70 years & $\begin{array}{c}\text { Patients younger than } 20 \text { or older } \\
\text { than } 70 \text { years of age }\end{array}$ \\
\hline $\begin{array}{l}\text { Patients evaluated from November } \\
2017 \text { to April } 2018\end{array}$ & $\begin{array}{c}\text { Known presence of spinal deformity } \\
\text { that would make radiological analysis } \\
\text { difficult }\end{array}$ \\
\hline Patients treated at the HEEC & $\begin{array}{l}\text { Patients who underwent previous } \\
\text { spine surgery }\end{array}$ \\
\hline $\begin{array}{l}\text { Patients submitted to radiographic } \\
\text { study of the spine performed in the } \\
\text { radiology department }\end{array}$ & Technically inadequate radiographs \\
\hline Technically adequate radiographs & $\begin{array}{c}\text { Patients with glenohumeral pain or } \\
\text { limitation }\end{array}$ \\
\hline $\begin{array}{l}\text { Patients who answered the } \\
\text { questionnaire }\end{array}$ & $\begin{array}{c}\text { Patients who refused to participate in } \\
\text { the research and did not fill out the } \\
\text { questionnaire }\end{array}$ \\
\hline $\begin{array}{l}\text { Patients who signed the Informed } \\
\text { Consent Form }\end{array}$ & $\begin{array}{c}\text { Patients who after filling out the ICF } \\
\text { and the questionnaire desisted from } \\
\text { undergoing the examination }\end{array}$ \\
\hline
\end{tabular}

Figure 3. Study inclusion and exclusion criteria.

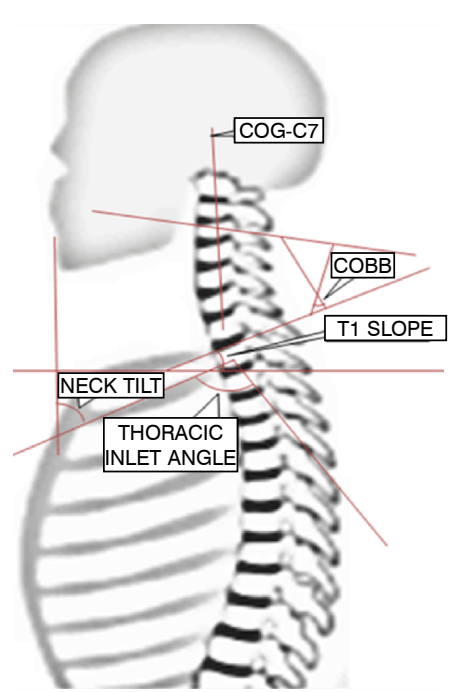

Figure 4. Schematized angles: COBB, NECK TILT, T1 SLOPE, THORACIC INLET ANGLE and COG-C7.

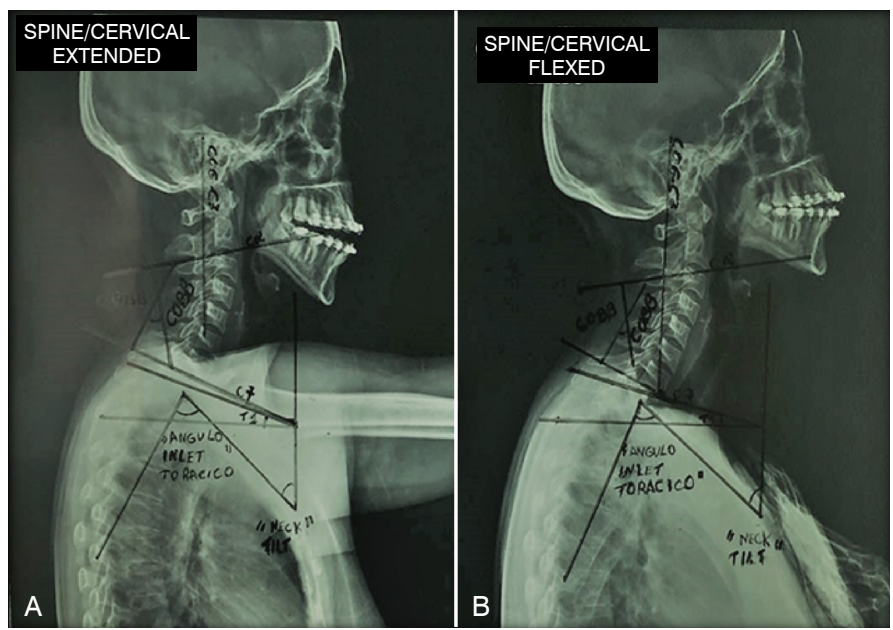

Figure 5. Lateral cervical spine radiographs in the two positions studied. Figure $A$ (on the left) with upper limbs raised at $90^{\circ}$ with elbows extended. Figure B (on the right) with upper limbs crossed over the trunk with elbows flexed.

The analyses were initiated by the distribution according to the frequency of the findings and the values of the angles obtained in the radiographic incidences in relation to the positioning of the arms during the examination. The demonstrative statistics were expressed as mean, median, mode, standard deviation, and paired t-test of the difference between the means, with a significance of $5 \%$. Graphs were produced by the Boxplot system, which indicates the existence of possible variables identifying the minimum, first quartile (Q1), median, third quartile (Q3), and the maximum.

\section{RESULTS}

One hundred and fifty patients were interviewed. Of these, 13 decided not to participate at the beginning of the study. The group remained with 137 patients (51 men and 86 women). Excluded from the study were one woman who had undergone previous spine surgery, 16 patients for not having radiographs taken, 15 patients with technically inadequate radiographs, and 5 patients with comorbidities in the shoulders that could alter the analysis of the parameters. Table 1 shows the final sample of 100 patients, $60 \%$ of whom were female and $40 \%$ of whom were males.

Table 2 shows the relationship between the degree of cervical 
spinal pain experienced by the study participants. Table 3 presents the variables studied as cervical angles measured with the upper limbs in different postures. Figures 6 to 10 show the statistical projection in graphical form (Boxplot) for interpretation of the five cervical parameters addressed.

\section{DISCUSSION}

Despite the importance of the angles in radiographs of the cervical spine, little attention has been given to the sagittal balance of this vertebral segment.

There are several studies related to lumbar sagittal balance, however it can be said that few publications address cervical sagittal balance. ${ }^{21,22}$

In the past, studies conducted on the relationship between spinal misalignment were largely focused on the thoracolumbar and pelvic regions, with comparatively little attention paid to the cervical segment. ${ }^{2,17,18,22}$

In their prospective study of 40 patients, Vedantam et al. ${ }^{15}$ compared a group of patients with cervical fusion to a group without cervical fusion. They concluded that there was no statistical difference $(p=0.0038)$ in cervical sagittal balance between the groups. However, positioning the arms at $90^{\circ}$ flexion versus $30^{\circ}$ flexion resulted in negative displacement of the sagittal vertical axis (SVA). It was statistically significant $(p=0.0038)$ for those with cervical fusion $\left(-6 \mathrm{~mm}\right.$ at $90^{\circ}$ versus $+4 \mathrm{~mm}$ at $\left.30^{\circ}\right)$ and $(p=0.119)$ for the patients without fusion of the cervical spine $\left(-8 \mathrm{~mm}\right.$ at $90^{\circ}$ versus $-4 \mathrm{~mm}$ at $\left.30^{\circ}\right)$. The authors found it ideal and recommend positioning the arms in front at $30^{\circ}$ of flexion to obtain a lateral radiograph without impacting cervical sagittal balance.

In the study by Kumagai et al. ${ }^{10}$ lateral cervical spine radiographs were taken with each participant standing and looking towards the front, supporting the shoulder against the chassis. Cervical sagittal alignment (C2-C7) was measured from the radiographs, using the method of the posterior tangent of the odontoid process and of

Table 1. Distribution of the patients by sex and age.

\begin{tabular}{|c|c|c|c|c|c|c|}
\hline $\begin{array}{l}\text { Men } \\
\text { Age }\end{array}$ & $\begin{array}{c}20-30 \\
\text { years }\end{array}$ & $\begin{array}{c}31-40 \\
\text { years }\end{array}$ & $\begin{array}{c}41-50 \\
\text { years }\end{array}$ & $\begin{array}{c}51-60 \\
\text { years }\end{array}$ & $\begin{array}{l}61-70 \\
\text { years }\end{array}$ & Total \\
\hline (N) & 4 & 8 & 7 & 13 & 8 & $\mathrm{~N}=40$ \\
\hline $\begin{array}{c}\text { Women } \\
\text { Age }\end{array}$ & $\begin{array}{c}20-30 \\
\text { years }\end{array}$ & $\begin{array}{c}31-40 \\
\text { years }\end{array}$ & $\begin{array}{c}41-50 \\
\text { years }\end{array}$ & $\begin{array}{c}51-60 \\
\text { years }\end{array}$ & $\begin{array}{l}61-70 \\
\text { years }\end{array}$ & \\
\hline (N) & 0 & 9 & 20 & 13 & 18 & $\mathrm{~N}=60$ \\
\hline
\end{tabular}

Table 2. Distribution of the patients by cervical spinal pain score.

\begin{tabular}{c|c|c|c|c|c}
\hline & $\begin{array}{c}\text { Without } \\
\text { cervical } \\
\text { spinal pain }\end{array}$ & $\begin{array}{c}\text { Pain score } \\
\mathbf{1}-\mathbf{4}\end{array}$ & $\begin{array}{c}\text { Pain score } \\
\mathbf{5 - 9}\end{array}$ & Pain $>\mathbf{1 0}$ & $\begin{array}{c}\text { Total number } \\
\text { of patients } \\
\text { with pain }\end{array}$ \\
\hline $\begin{array}{c}\text { Men } \\
(\mathrm{N}=40)\end{array}$ & 38 & 1 & 1 & 0 & 2 \\
\hline $\begin{array}{c}\text { Women } \\
(\mathrm{N}=60)\end{array}$ & 38 & 10 & 10 & 2 & 22 \\
\hline
\end{tabular}

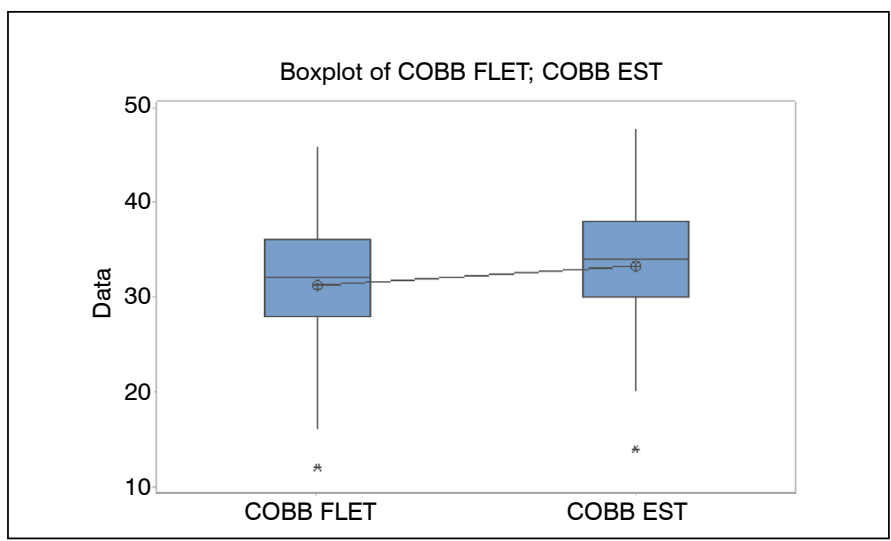

Figure 6. Boxplot of difference between the means $(p=0.000)$ Cobb Flex vs. Cobb Ext.

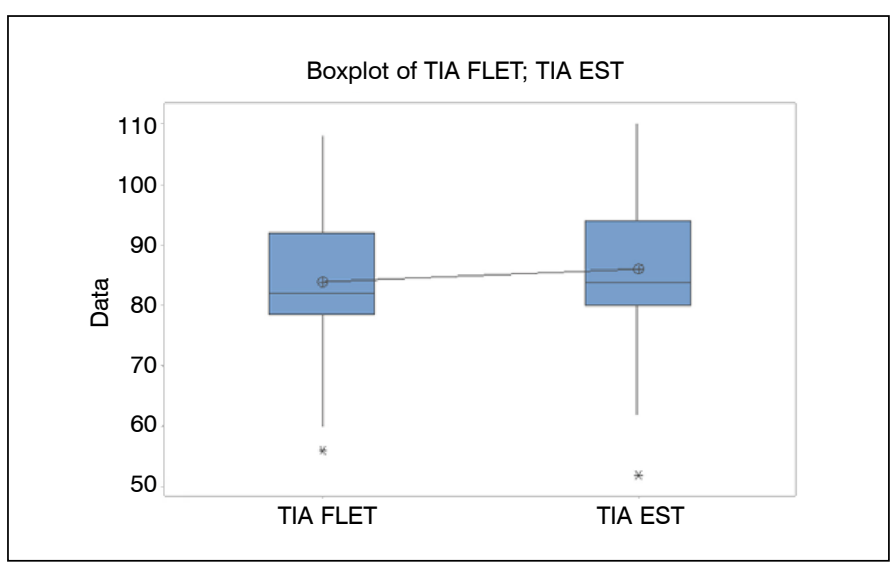

Figure 7. Boxplot of difference between the means $(p=0.000)$ TIA Flex vs. TIA Ext.

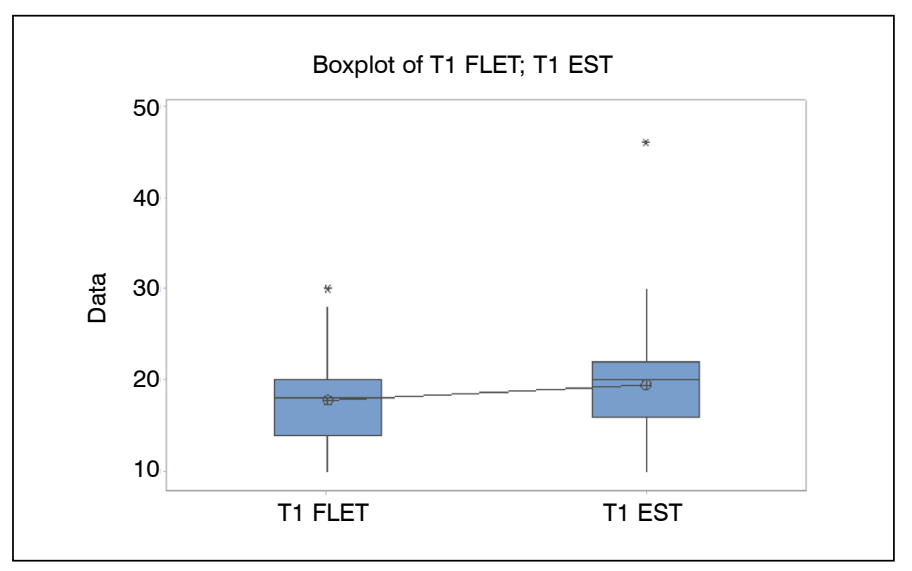

Figure 8. Boxplot of difference between means $(p=0.000)$ T1 Flex vs. T1 Ext.

Table 3. Descriptive statistics for the total patient sample, =100: Cobb, TIA, T1, COG-C7, Neck tilt (Flex vs. Ext).

\begin{tabular}{c|c|c|c|c|c|c|c|c}
\hline & $\begin{array}{c}\text { Total } \\
\mathbf{N = 1 0 0}\end{array}$ & Mean & $\begin{array}{c}\text { Standard } \\
\text { Deviation }\end{array}$ & Minimum & Q1 & Median & Q3 & Maximum \\
\hline Cobb Flex & & $31^{\circ} .270$ & 6.636 & $12^{\circ} .000$ & 28.000 & $32^{\circ} .000$ & 36.000 & $46^{\circ} .000$ \\
\hline Cobb Ext & & $33^{\circ} .300$ & 6.693 & $14^{\circ} .000$ & 30.000 & $34^{\circ} .000$ & 38.000 & $48^{\circ} .000$ \\
\hline TIA Flex & & $83^{\circ} .88$ & 10.70 & $56^{\circ} .00$ & 78.50 & $82^{\circ} .00$ & 92.00 & $108^{\circ} .00$ \\
\hline TIA Ext & & $85^{\circ} .94$ & 10.66 & $52^{\circ} .00$ & 80.00 & $84^{\circ} .00$ & 94.00 & $110^{\circ} .00$ \\
\hline T1 Flex & & $17^{\circ} .740$ & 4.410 & $10^{\circ} .000$ & 14.000 & 18.000 & 20.000 & $30^{\circ} .000$ \\
\hline T1 Ext & & $19^{\circ} .520$ & 4.834 & $10^{\circ} .000$ & 16.000 & 20.000 & 22.000 & $46^{\circ} .000$ \\
\hline Neck tilt Flex & & $44^{\circ} .300$ & 8.449 & 18.000 & 40.000 & 44.000 & 50.000 & $62^{\circ} .000$ \\
\hline Neck tilt Ext & & $46^{\circ} .460$ & 8.494 & $20^{\circ} .000$ & 42.000 & 46.000 & 52.000 & $64^{\circ} .000$ \\
\hline COG-C7 Flex & & $15.19 \mathrm{~cm}$ & 17.69 & $8.00 \mathrm{~cm}$ & 10.03 & $14.05 \mathrm{~cm}$ & 16.50 & $18.70 \mathrm{~cm}$ \\
\hline COG-C7 Ext & & $13.811 \mathrm{~cm}$ & 3.165 & $8.000 \mathrm{~cm}$ & 10.350 & $14.500 \mathrm{~cm}$ & 16.875 & $19.300 \mathrm{~cm}$ \\
\hline
\end{tabular}




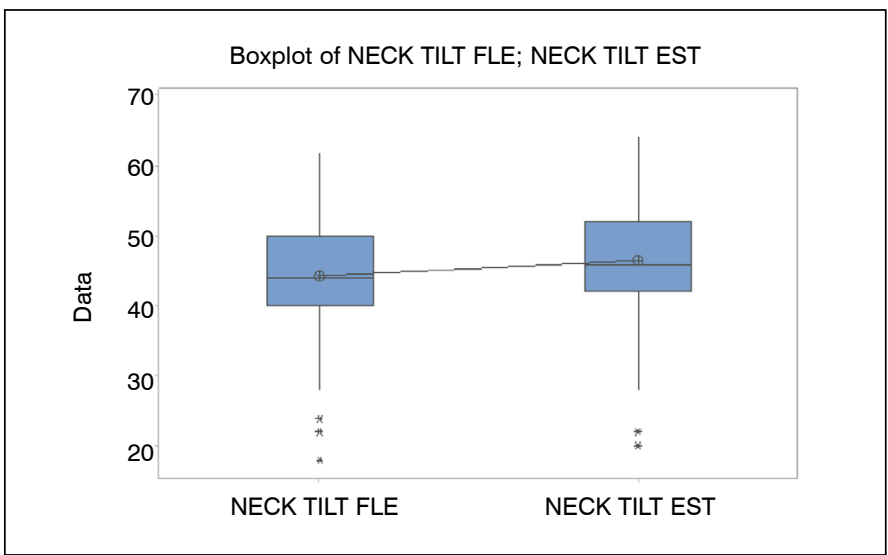

Figure 9. Boxplot of the difference between means $(p=0.000)$ Neck tilt Flex vs. Neck tilt Ext.

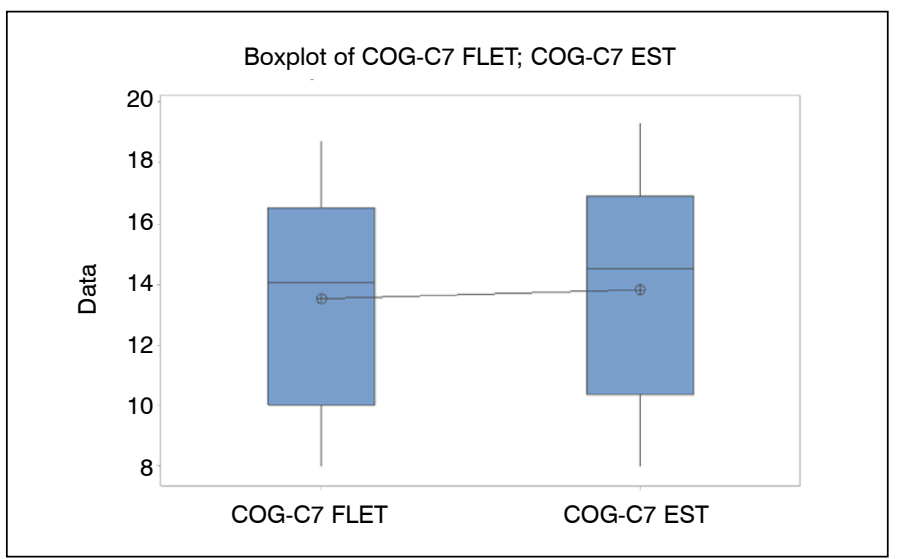

Figure 10. Boxplot of the difference between the means $(p=0.000)$ COG-C7 Flex vs. COG-C7 Ext.

the vertebral body of $\mathrm{C} 7$, and three groups were defined: straight spine $\left(-4^{\circ}\right.$ to $\left.+4^{\circ}\right)$, lordotic spine (less than $\left.-4^{\circ}\right)$, and kyphotic spine (more than $\left.+4^{\circ}\right) .{ }^{10}$

In their magnetic resonance study, Janusz et al. ${ }^{22}$ found mean sagittal balance values of the TIA equal to $71^{\circ} .7 \pm 9.5$, T1 slope equal to $26^{\circ} .7 \pm 6.3$, and neck tilt equal to $44^{\circ} .9 \pm 7.2$.

Because studies of sagittal balance are recent, there is not yet consensus around these values in the literature. ${ }^{18,23,24}$ However, Weng et al. ${ }^{23}$ reported sagittal balance values of the TIA $\left(78^{\circ}\right)$, T1 slope $\mathrm{T} 1\left(44^{\circ}, 88\right)$, and mean Cobb C2-C7 $\left(15^{\circ}, 4.\right)$ in their radiographic study.

It can be said that the Cobb method was the most used in the studies encountered and continues to be used to measure cervical lordosis because of its ease of use, as well as its reliability and reproducibility among examiners. ${ }^{6,10,13,15,24}$

The age range used in our study was 20 to 70 years for both sexes. This was divided into age bands of $20-30$ years, $31-40$ years, 41-50 years, 51-60 years, and 61-70 years and cervical pain was evaluated and graded. We observed that when patients in a public hospital answer a pain questionnaire and subsequently grade it, given the possibility of obtaining Social Security, they need to refer to their pain as being from moderate pain to the worst pain they have ever had, even without physical therapy or drug treatment.

The cervical spine is a mechanical structure to support the head with the neck with six degrees of freedom of movement. The main movements of the cervical spine are flexion, extension, axial rotation, and lateral flexion, together with a small number of anterior and posterior translational movements along the sagittal cervical axis. ${ }^{17,25,26}$

The kinematics of the cervical spine are therefore impaired by the anatomy of the bones that make up the neck and the joints that connect them. Under normal conditions, flexion is limited by the tension in the posterior neck muscles and by the impaction of mandibular tissues. Extension, on the other hand, is limited by the suboccipital muscles. 5,10,22,25,26

The cervical spine is able to move within the neutral zone with little force, thus requiring little energy expenditure by the paravertebral muscles. Additional movements outside the neutral zone require more effort. The elastic strength of the soft tissues requires more energy expenditure. ${ }^{13,14,23,26}$

Extension is initiated in the low cervical spine (C4 \pm 7 ), but the order of individual segment contribution is variable. This is followed by the start of movement in $\mathrm{C} 0 \pm \mathrm{C} 2$ and $\mathrm{C} 2 \pm \mathrm{C} 4$. Between $\mathrm{C} 2$ and $\mathrm{C} 4$ the order of contribution is quite variable. The final phase of extension is marked by a second contribution from $\mathrm{C} 4 \pm 7$ in which the individual segments move in the order $\pm \mathrm{C} 4 \pm 5, \mathrm{C} 5 \pm$ $6, \mathrm{C} 6 \pm 7 .{ }^{17,22,26}$

Flexion is initiated in the low cervical spine (C4 \pm 7$)$. Within this block and during the initial phase segment $\mathrm{C} 6 \pm 7$ regularly makes its contribution before $\mathrm{C} 5 \pm 6$, followed by $\mathrm{C} 4 \pm 5$. Flexion is thus initiated and terminated by $\mathrm{C} 6 \pm 7$. It is never initiated in middle cervical levels. $\mathrm{C} 0 \pm \mathrm{C} 2, \mathrm{C} 2 \pm 3$, and $\mathrm{C} 3 \pm 4$ make their maximum contribution during the middle of the movement, but in variable order. ${ }^{25,26}$

It can be said that, due to spinal kinematics, flexion movements of the spine expend more energy and have more limitations, as seen in those studied above. This fact was confirmed in our study, in which the five variables studied were observed to have greater angulations when the upper limbs were raised forward (elbows extended).

\section{CONCLUSION}

Analysis of the data obtained demonstrated the statistical significance of the positioning of the upper limbs in profile radiographs, where we observed greater angle values with the arms raised towards the front (elbows extended). Such a difference can alter sagittal cervical balance, influencing surgical planning. New studies must be conducted to prove this finding.

\section{ACKNOWLEDGEMENTS}

To Sr. Luiz Antônio Sizenando de Queiroz, the radiology technician.

All authors declare no potential conflict of interest related to this article.

CONTRIBUTION OF THE AUTHORS: Each author made significant individual contributions to this manuscript. Study concept and design: VML. Statistics: NMO. Data analysis and interpretation: VML, GRT and NMO. Development of the article: VML and GRT. Critical review of the article: GRT. Revision of the final version for submission: VML, GRT, NMO.

\section{REFERENCES}

1. Duval-Beaupère G, Schmidt C, Cosson P. A Barycentremetric Study of The Sagitta Shape of Spine and Pelvis: The Conditions Required For An Economic Standing Position. Ann Biomed Eng. 1992;20(4):451-62

2. Smith JS, Shaffrey Cl, Fu KM, Scheer JK, Bess S, Lafage V, et al. Clinical and Radiographic Evaluation of the Adult Spinal Deformity Patient. Neurosurg Clin N Am. 2013;24(2):143-56. doi: 10.1016/j.nec.2012.12.009
3. Wang ZL, Xiao JL, Mou JH, Qin TZ, Liu P. Analysis of Cervical Sagittal Balance Parameters in MRIs of Patients with Disc-Degenerative Disease. Med Sci Monit. 2015;21:3083-8. doi: 10.12659/MSM.893715

4. Lee SH, Son ES, Seo EM, Suk KS, Kim KT. Factors Determining Cervical Spine Sagittal Balance in Asymptomatic Adults: Correlation with Spinopelvic Balance and Thoracic Inlet Alignment. Spine J. 2015;15(4):705-12. doi: 10.1016/j.spinee.2013.06.059 
5. Hardacker JW, Shuford RF, Capicotto PN, Pryor PW. Radiographic Standing Cervical Segmental Alignment in Adult Volunteers Without Neck Symptoms. Spine (Phila Pa 1976). 1997:22(13):1472-80. doi: 10.1097/00007632-199707010-00009

6. Colachis SC Jr, Strohm BR. Radiographic Studies of Cervical Spinemotion in Normal Subjects: Flexion and Hyperextension. Arch Phys Med Rehabil. 1965;46(11):753-60.

7. Ozdogan S, Koken M, Duzkalir HG, Duzkalir AH, Yaltirik CK, Ozturk E, et al. Brief Review on Fundamentals of Cervical Spine Alignment. The Journal of Turkish Spinal Surgery. 2017;28(1):53-60.

8. Siasios I, Winograd E, Khan A, Vakharia K, Dimopoulos VG, Pollina J. Cervical Sagittal Balance Parameters After Single-Level Anterior Cervical Discectomy and Fusion: Correlations with Clinical and Functional Outcomes. J Craniovertebr Junction Spine. 2018;9(1):56-62. doi: 10.4103/jcvjs.JCVJS9918

9. Lee SH, Kim KT, Seo EM, Suk KS, Kwack YH, Son ES, et al. The Influence of Thoracic in Let Alignment on the Craniocervical Sagittal Balance in Asymptomatic Adults. J Spinal Disord Tech. 2012;25(2):E41-7. doi: 10.1097/BSD.0b013e3182396301

10. Kumagai G, Ono A, Numasawa T, Wada K, Inoue R, Iwasaki H, et al. Association Between Roentgenographic Findings of The Cervical Spine and Neck Symptoms in a Japanese Community Population. J Orthop Sci. 2014;19(3):390-7. doi: 10.1007/s00776-014-0549-8

11. Chapman CR, Casey KL, Dubner R, Foley KM, Gracely RH, Reading AE. Pain measurement: An Overview. Pain. 1985:22(1):1-31. doi: 10.1016/0304-3959(85)90145-9

12. Dvorak J, Froehlich D, Penning L, Baumgartner H, Panjabi MM. Functional Radiographic Diagnosis of the Cervical Spine: Flexion/Extension. Spine (Phila Pa 1976). 1988;13(7):748-55. doi: 10.1097/00007632-198807000-00007

13. Lin RM, Tsai KH, Chu LP Chang PO Characteristics of Sagittal Vertebral Alignment in Flexion Determined by Functional Radiographs of the Cervical Spine. Spine (Phila Pa 1976). 2001;26(3):256-61. doi: 10.1097/00007632-200102010-00010

14. Takeshima T, Omokawa S, Takaoka T, Araki M, Ueda Y, Takakura Y. Sagittal Alignment of Cervical Flexion and Extension Lateral Radiographic Analysis. Spine (Phila Pa 1976). 2002;27(15):E348-55. doi: 10.1097/00007632-200208010-00014

15. Vedantam R, Lenke LG, Bridwell KH, Linville DL, Blanke K. The Effect of Variation in Arm Position on Sagittal Spinal Alignment. Spine (Phila Pa 1976). 2000;25(17):2204-9. doi: 10.1097/00007632-200009010-00011

16. Lima DP, Sties SW, Gonzales AI, Bundchen DC, Aquino IG, Carvalho T, et al Questionário Para Avaliação da Dor Musculoesquelética em Praticantes de Exer- cício (Q-ADOM). Rev Bras Med Esporte. 2016;22(5):374-80. doi:10.1590/1517 869220162205161347

17. Koeppen D, Piepenbrock C, Kroppenstedt S, Cabraja M. The Influence of Sagitta Profile Alteration and Final Lordosis on the Clinical Outcome of Cervical Spondylotic Myelopathy. A Delta-Omega-Analysis. PloSOne. 2017;12(4):1-14. doi: 10.1371/journal.pone. 0174527

18. Lima MC, Risso NMI, Zuani GR, Veiga IG, Tebet MA, Pasqualini W, et al. Parâmetros de Avaliação do Equilíbrio Sagital Cervical na Escoliose Idiopática. Coluna/Columna. 2017:16(1):38-41. doi:10.1590/s1808-185120171601

19. Tang JA, Scheer JK, Smith JS, Deviren V, Bess S, Hart RA, et al. The Impact of Standing Regional Cervical Sagittal Alignment on Outcomes in Posterior Cervical Fusion Surgery. Neurosurgery. 2012:71(3):662-9. doi: 10.1227/NEU.0b013e31826100c9

20. Gore DR, Sepic SB, Gardner GM. Roentgenographic Findings of the Cervical Spine in Asymptomatic People. Spine (Phila Pa 1976). 1986;11(6):521-4. doi: 10.1097/00007632198607000-00003

21. Gore DR. Roentgenographic Findings in the Cervical Spine in Asymptomatic Persons: A Tenyear Follow-up. Spine (Phila Pa 1976). 2001;26(22):2463-6. doi: 10.1097/00007632200111150-00013

22. Janusz P, Tyrakowski M, Glowka P, Offoha R, Siemionow K. Influence of Cervical Spine Position on The Radiographic Parameters of the Thoracic Inlet Alignment. Eur Spine J. 2015;24(12):2880-4. doi: 10.1007/s00586-015-4023-x

23. Weng C, Wang J, Tuchman A, Wang J, Fu C, Hsieh PC, et al. Influence of T1 Slope on the Cervical Sagittal Balance in Degenerative Cervical Spine: An Analysis Using Kinematic MRI. Spine (Phila Pa 1976). 2016;41(3):185-90. doi: 10.1097/ BRS.0000000000001353

24. Scheer JK, Tang JA, Smith JS, Acosta FL Jr, Protopsaltis TS, Blonde LB, et al. Cervical Spine Alignment, Sagittal Deformity, and Clinical Implications: A review. J Neurosurg Spine. 2013;19(2):141-59. doi: 10.3171/2013.4.SPINE12838

25. Bogduk N, Mercer S. Biomechanics of the cervical spine. I: Normal kinematics. Clin Biomech (Bristol, Avon). 2000;15(9):633-48. doi: 10.1016/s0268-0033(00)00034-6

26. Tan LA, Riew KD, Traynelis VC. Cervical Spine Deformity-Part 1: Biomechanics, Radiographic Parameters, and Classification. Neurosurgery. 2017;81(2):197-203. doi: 10.1093/neuros/nyx249. 